AJIE - Asian Journal of Innovation and Entrepreneurship

(e-ISSN: 2477- 0574; p-ISSN: 2477-3824)

Vol. 02, No. 01, January 2017

\title{
UKURAN PERUSAHAAN, PROFITABILITAS, VOLATILITAS \\ PENDAPATAN, DAN RESIKO BISNIS TERHADAP NILAI \\ PERUSAHAAN DENGAN KEBIJAKAN HUTANG SEBAGAI \\ VARIABEL MODERATING PADA SAHAM JII \\ (JAKARTA ISLAMIC INDEX) \\ DI BURSA EFEK INDONESIA
}

\author{
Firmansyah, Zubir \\ ${ }^{1}$ Sekolah Tinggi Ilmu Ekonomi (STIE) Mahaputra Riau, Pekanbaru, Indonesia
}

\begin{abstract}
The way to maximize shareholder value is to increase the rate of return on the investment. For companies that have not gone public can be seen from the increase in the assets of companies, and for companies that have gone public can be seen from the price of shares in the capital market. In other words, if the stock price rises, the value of the company has increased as well and vice versa, if the price of the stock has decreased the value perusahaa decline and thus will affect the company's shareholders. However, due to the company's value can be some factors such as company size, profitability, volatility of income, debts and business risk..

The goals of this research is the first to investigate the effect of firm size on firm value on the stock JII (Jakarta Islamic Index) at the Indonesian Stock Exchange, the second to determine the effect the profitability of the company's value on the stock JII (Jakarta Islamic Index) at the Indonesian Stock Exchange, the third to determine the effect of earnings volatility on the value of the company on the stock JII (Jakarta Islamic Index) at the Indonesian stock Exchange, the fourth to determine the effect of business risk against the value of the company on the stock JII (Jakarta Islamic Index) at the Indonesian stock Exchange, the fifth to determine the effect of firm size and debt policy on firm value on the stock JII (Jakarta Islamic Index) at the Indonesian stock Exchange, the sixth to determine the effect of profitability and debt policy to the value of the company on the stock JII (Jakarta Islamic Index) at the Indonesian stock Exchange, the seventh to learn to know the effect of earnings volatility and debt policy to the value of the company shares JII (Jakarta Islamic Index) at the Indonesian stock Exchange, the eighth to determine the effect of business risk and debt policy to the value of the company shares JII (Jakarta Islamic Index) at the Indonesian stock Exchange.

The results showed that simultaneous company size, profitability, earnings volatility and business risk effect simultaneously on the company's value on the stock JII (Jakarta Islamic Index) at the Indonesian Stock Exchange, partially earnings volatility effect on the value of the company at sahaam JII (Jakarta Islamic Index) at the Indonesian Stock Exchange, shows that the debt policy does not provide relationship between firm size, profitability, risk binis with the value of the company, while earnings volatility provides the link to the value of the company with debt policy as a moderating.
\end{abstract}


Keywords: Company Size, Profitability, Revenue Volatility, Risk Business, Corporate Values and Debt Policy

\begin{abstract}
ABSTRAK
Cara untuk memaksimumkan nilai pemegang saham adalah dengan cara meningkat tingkat pengembalian dari investasi tersebut. Bagi perusahaan yang belum go public dapat diketahui dari naiknya aktiva perusahaan, dan bagi perusahaan yang telah go public dapat diketahui dari harga saham di pasar modal. Dengan kata lain apabila harga saham naik maka nilai perusahaan mengalami kenaikan juga dan sebaliknya apabila harga saham mengalami penurunan maka nilai perusahaa mengalami penurunan sehingga akan berdampak bagi pemegang saham perusahaan. Akan tetapi nilai perusahaan dapat disebabkan oleh beberap faktor diantaranya ukuran perusahaan, profitabilitas, volatilitas pendapatan, hutang dan resiko bisnis..

Tujuan yang diharapkan dari penelitian ini pertama untuk mengetahui pengaruh ukuran perusahaan terhadap nilai perusahaan pada saham JII (Jakarta Islamic Indeks) di Bursa Efek Indonesia, kedua untuk mengetahui pengaruh profitabilitas terhadap nilai perusahaan pada saham JII (Jakarta Islamic Indeks) di Bursa Efek Indonesia, ketiga untuk mengetahui pengaruh volatilitas pendapatan terhadap nilai perusahaan pada saham JII (Jakarta Islamic Indeks) di Bursa Efek Indonesia, keempat untuk mengetahui pengaruh resiko bisnis terhadap nilai perusahaan pada saham JII (Jakarta Islamic Indeks) di Bursa Efek Indonesia, kelima untuk mengetahui pengaruh ukuran perusahaan dan kebijakan hutang terhadap nilai perusahaan pada saham JII (Jakarta Islamic Indeks) di Bursa Efek Indonesia, keenam untuk mengetahui pengaruh profitabilitas dan kebijakan hutang terhadap nilai perusahaan pada saham JII (Jakarta Islamic Indeks) di Bursa Efek Indonesia, ketujuh untuk mengetahui untuk mengetahui pengaruh volatilitas pendapatan dan kebijakan hutang terhadap nilai perusahaan pada saham JII (Jakarta Islamic Indeks) di Bursa Efek Indonesia, kedelapan untuk mengetahui pengaruh resiko bisnis dan kebijakan hutang terhadap nilai perusahaan pada saham JII (Jakarta Islamic Indeks) di Bursa Efek Indonesia.

Hasil penelitian menunjukkan bahwa secara simultan ukuran perusahaan, profitabilitas, volatilitas pendapatan, dan resiko bisnis berpengaruh simultan terhadap nilai perusahaan pada saham JII (Jakarta Islamic Indeks) di Bursa Efek Indonesia, secara parsial volatilitas pendapatan berpengaruh terhadap terhadap nilai perusahaan pada sahaam JII (Jakarta Islamic Indeks) di Bursa Efek Indonesia, menunjukkan bahwa kebijakan hutang tidak memberikan hubungan antara ukuran perusahaan, profitabilitas, resiko binis dengan nilai perusahaan, sedangkan volatilitas pendapatan memberikan hubungan terhadap nilai perusahaan dengan kebijakan hutang sebagai moderating.
\end{abstract}

Keywords:Ukuran Perusahaan, Profitabilitas, Volatilitas Pendapatan, Resiko Bisnis, Nilai Perusahaan, dan Kebijakan Hutang

\section{PENDAHULUAN}

Sebuah perusahaan didirikan bertujuan untuk mendapatkan keuntungan atau laba, akan tetapi keuntungan memiliki tujuan akhir yaitu memaksimumkan nilai pemegang nilai.

Cara untuk memaksimumkan nilai pemegang saham adalah dengan cara 
meningkat tingkat pengembalian dari investasi tersebut. Bagi perusahaan yang belum go public dapat diketahui dari naiknya aktiva perusahaan, dan bagi perusahaan yang telah go public dapat diketahui dari harga saham di pasar modal. Dengan kata lain apabila harga saham naik maka nilai perusahaan mengalami kenaikan juga dan sebaliknya apabila harga saham mengalami penurunan maka nilai perusahaa mengalami penurunan sehingga akan berdampak bagi pemegang saham perusahaan.
Akan tetapi nilai perusahaan dapat disebabkan oleh beberap faktor diantaranya ukuran perusahaan, profitabilitas, volatilitas pendapatan, hutang dan resiko bisnis. Penelitian ini dilakukan pada saham JII (Jakarta Islamic Index) disebabkan bahwa saham perusahaan memiliki keuntungan yang stabil setiap tahunnya. Berikut ini data ukuran perusahaan, profitabilitas, volatilitas pendapatan, kebijakan hutang dan nilai perusahaan :

\begin{tabular}{|c|c|c|c|c|c|c|c|c|c|c|c|c|}
\hline & \multicolumn{2}{|c|}{ Ukuran Perusahaan } & \multicolumn{2}{|c|}{ Profittabilitas } & \multicolumn{2}{|c|}{ Resiko Bisnis } & \multicolumn{2}{|c|}{ Volatilitas Pendaratan } & \multicolumn{2}{|c|}{ Nillai Perusahlaan } & \multicolumn{2}{|c|}{ Kebjijkan Hutang } \\
\hline & & & & & 2014 & 3015 & & 2015 & & 2015 & 2011 & 2015 \\
\hline tort & & & 0.12 & & & & & 0.20 & & & & 0.14 \\
\hline $2 A D$ & & & & & & & & & & & & 0.37 \\
\hline AKRA & $663,141,381$ & $14,791,1917,177$ & 0,04 & 0.02 & 0.05 & -0.05 & Wht & 0.05 & 4,375 & 4,120 & 0.18 & 0.18 \\
\hline
\end{tabular}

Pada tabel diatas dapat diketahui bahwa naiknya ataupun turunya ukuran perusahan diikuti dengan nilai perusahaan, hal ini sesuai dengan yang dikatakan oleh Pratama dan I Gusti Bagus Wiksuana (2016) yang hasilnya bahwa ukuran perusahaan berpengaruh positif terhadap nilai perusahaan, profitabilitas diikuti oleh naik atau turunya nilai perusahaan hal ini sesuai dengan yang dikatakan oleh Pratama dan I Gusti Bagus Wiksuana (2016) yang hasilnya bahwa profitabilitas berpengaruh positif terhadap nilai perusahaan, naik atau turunya resiko bisnis selalu diikuti oleh turunya nilai perusahaan , dan begitu juga pada variabel volatilitas pendapatan maupun kebijakan hutang.

Dengan didasarkan pada hasil penelitian sebelumnya mengalami perbedaan yaitu nilai perusahaan pada penelitian ini di ukur dengan harga saham perusahaan.

Tujuan yang diharapkan dari penelitian ini pertama untuk mengetahui pengaruh ukuran perusahaan terhadap nilai perusahaan pada saham JII (Jakarta Islamic Indeks) di Bursa Efek Indonesia, kedua untuk mengetahui pengaruh profitabilitas terhadap nilai perusahaan pada saham JII (Jakarta Islamic Indeks) di Bursa Efek Indonesia, ketiga untuk mengetahui pengaruh volatilitas pendapatan terhadap nilai perusahaan pada saham JII (Jakarta Islamic Indeks) di Bursa Efek Indonesia, keempat untuk mengetahui pengaruh resiko bisnis terhadap nilai perusahaan pada saham JII (Jakarta Islamic Indeks) di Bursa Efek Indonesia, kelima untuk mengetahui pengaruh ukuran perusahaan dan kebijakan hutang terhadap nilai perusahaan pada saham JII (Jakarta 
Islamic Indeks) di Bursa Efek Indonesia, keenam untuk mengetahui pengaruh profitabilitas dan kebijakan hutang terhadap nilai perusahaan pada saham JII (Jakarta Islamic Indeks) di Bursa Efek Indonesia, ketujuh untuk mengetahui untuk mengetahui pengaruh volatilitas pendapatan dan kebijakan hutang terhadap nilai perusahaan pada saham JII (Jakarta Islamic Indeks) di Bursa Efek Indonesia, kedelapan untuk mengetahui pengaruh resiko bisnis dan kebijakan hutang terhadap nilai perusahaan pada saham JII (Jakarta Islamic Indeks) di Bursa Efek Indonesia.

\section{PERUMUSAN MASALAH}

1. Apakah ukuran perusahaan berpengaruh terhadap nilai perusahaan pada saham JII (Jakarta Islamic Indeks) di Bursa Efek Indonesia?.

2. Apakah profitabilitas berpengaruh terhadap nilai perusahaan pada saham JII (Jakarta Islamic Indeks) di Bursa Efek Indonesia?.

3. Apakah volatilitas pendapatan terhadap berpengaruh nilai perusahaan pada saham JII (Jakarta Islamic Indeks) di Bursa Efek Indonesia?.

4. Untuk mengetahui pengaruh resiko bisnis terhadap nilai perusahaan pada saham JII (Jakarta Islamic Indeks) di Bursa Efek Indonesia?.

5. Apakah ukuran perusahaan dan kebijakan hutang berpengaruh terhadap nilai perusahaan pada saham JII (Jakarta Islamic Indeks) di Bursa Efek Indonesia?.

6. Apakah profitabilitas dan kebijakan hutang berpengaruh terhadap nilai perusahaan pada saham JII (Jakarta Islamic Indeks) di Bursa Efek Indonesia?.
7. Apakah volatilitas pendapatan dan kebijakan hutang berpengaruh terhadap nilai perusahaan pada saham JII (Jakarta Islamic Indeks) di Bursa Efek Indonesia?.

8. Apakah resiko bisnis dan kebijakan hutang berpengaruh terhadap nilai perusahaan pada saham JII (Jakarta Islamic Indeks) di Bursa Efek Indonesia?.

\section{TUJUAN PENELITIAN}

1. Untuk mengetahui pengaruh ukuran perusahaan terhadap nilai perusahaan pada saham JII (Jakarta Islamic Indeks) di Bursa Efek Indonesia.

2. Untuk mengetahui pengaruh profitabilitas terhadap nilai perusahaan pada saham JII (Jakarta Islamic Indeks) di Bursa Efek Indonesia.

3. Untuk mengetahui pengaruh volatilitas pendapatan terhadap nilai perusahaan pada saham JII (Jakarta Islamic Indeks) di Bursa Efek Indonesia.

4. Untuk mengetahui pengaruh resiko bisnis terhadap nilai perusahaan pada saham JII (Jakarta Islamic Indeks) di Bursa Efek Indonesia.

5. Untuk mengetahui pengaruh ukuran perusahaan dan kebijakan hutang terhadap nilai perusahaan pada saham JII (Jakarta Islamic Indeks) di Bursa Efek Indonesia.

6. Untuk mengetahui pengaruh profitabilitas dan kebijakan hutang terhadap nilai perusahaan pada saham JII (Jakarta Islamic Indeks) di Bursa Efek Indonesia.

7. Untuk mengetahui untuk mengetahui pengaruh volatilitas pendapatan dan kebijakan hutang terhadap nilai perusahaan pada saham JII (Jakarta Islamic Indeks) di Bursa Efek Indonesia. 
8. Untuk mengetahui pengaruh resiko bisnis dan kebijakan hutang terhadap nilai perusahaan pada saham JII (Jakarta Islamic Indeks) di Bursa Efek Indonesia.

\section{LANDASAN TEORITIS}

\section{Teori Penelitian}

\section{a. Nilai Perusahaan}

\section{b. Kebijakan Hutang}

Menunjukkan total hutang jangka panjang yang dimiliki oleh perusahaan yang digunakan untuk membiayai kegiatan operasionalnya (Vidyantie dan Handayani Dalam Imanta dan Satwiko,2011).

\section{c. Ukuran Perusahaan}

Ukuran perusahaan merupakan menggambarkan kekayaan yang dimiliki oleh perusahaan (Vidyantie dan Handayani Dalam Imanta dan Satwiko,2011).

\section{d. Profitabilitas}

Profitabilitas dalam penelitian ini di ukur dengan menggunakan return on asset (ROA). Return on asset mencerminkan seberapa besaqr return yang dihasilkan atas setiap rupiah yang yang ditanamkan dalam bentuk asset (Murhadi,2013)

\section{e. Volatilitas Pendapatan}

Volatilitas pendapatan merupakan tingkat resiko bisnis dan tingkat kebangkrutan perusahaan (Vidyantie dan Handayani Dalam Imanta dan Satwiko,2011).

\section{f. Resiko Bisnis}

Resiko bisnis merupakan indikator ketidakstabilan harga saham dan return yang diterima oleh pemegang saham (Vidyantie dan Handayani Dalam Imanta dan Satwiko,2011).

\section{Penelitian Terdahulu}

Hasania dkk (2016), melakukan penelitiannya dengan judul "Pengaruh Current Ratio, Ukuran Perusahaan, Struktur Modal, dan ROE Terhadap Nilai Perusahaan Farmasai yang Terdaftar Di Bursa Efek Indonesia Periode 2011 2014". Hasil penelitian menunjukkan bahwa Current Ratio (CR) berpengaruh secara signifikan terhadap Nilai Perusahaan. Variabel Ukuran Perusahaan tidak berpengaruh signifikan terhadap Nilai Perusahaan. Variabel Struktur Modal berpengaruh secara signifikan terhadap Nilai Perusahaan. Variabel ROE berpengaruh secara signifikan terhadap Nilai Perusahaan. Dan secara simultan CR, Ukuran Perusahaan, Struktur Modal, dan ROE berpengaruh secara signifikan terhadap Nilai Perusahaan.

Novari dan Putu Vivi Lestari (2016), melakukan penelitian dengan judul "Pengaruh Ukuran Perusahaan, Leverage dan Profitabilitas Terhadap Nilai Perusahaan Pada Sektor Properti dan Real Estate. Hasil penelitian menunjukkan bahwa kuran perusahaan berpengaruh positif dan signifikan terhadap nilai perusahaan, leverage tidak berpengaruh signifikan terhadap nilai perusahaan, dan profitabilitas berpengaruh positif dan signifikan terhadap nilai perusahaan.

Pratama dan I Gusti Bagus Wiksuana (2016), melakukan penelitiannya dengan judul "Pengaruh Ukuran Perusahaan dan Leverage Terhadap Nilai Perusahaan Dengan Profitabilitas Sebagai Variabel Mediasi”. Hasil penelitian menunjukkan bahwa ukuran perusahaan, leverage dan profitabilitas berpengaruh positif signifikan terhadap nilai perusahaan. Ukuran Perusahaan dan leverage berpengaruh positif signifikan terhadap 
Profitabilitas. Namun profitabilitas tidak mampu memediasi pengaruh Ukuran perusahaan terhadap nilai Perusahaan serta Profitabilitas tidak mampu memediasi pengaruh leverage terhadap nilai perusahaan.

Pratiwi dkk (2016), melakukan penelitiannya dengan judul "Pengaruh Struktur Modal dan Ukuran Perusahaan Terhadap Nilai Perusahaan". Hasil penelitian menunjukkan bahwa ada pengaruh positif dan signifikan dari Struktur Modal dan Ukuran Perusahaan terhadap Nilai Perusahaan dengan sumbangan pengaruh sebesar $65,4 \%$, ada pengaruh positif dan signifikan dari Struktur Modal terhadap Nilai Perusahaan dengan sumbangan pengaruh sebesar $80,9 \%$,ada pengaruh positif dan signifikan dari Ukuran Perusahaan terhadap Nilai Perusahaan dengan sumbangan pengaruh sebesa $10,4 \%$.

Rudangga dan Gede Merta Sudiarta (2016), melakukan penelitiannya dengan judul "Pengaruh Ukuran Perusahaan, Leverage dan Profitabilitas Terhadap Nilai Perusahaan". Hasil penelitian menunjukkan bahwa ukuran perusahaan berpengaruh positif terhadapnilai perusahaan, leverage berpengaruh positif terhadap nilai perusahaan, dan profitabilitas berpengaruh positif terhadap nilai perusahaan.

\section{METODE PENELITIAN}

Jenis penelitian ini adalah dengan menggunakan jenis penelitian eksplanatori.

Jenis dan sumber data menurut memperolehnya pada penelitian ini dengan menggunakan data sekunder. Data sekunder merupakan data yang diperoleh atau dikumpulkan oleh orang yang melakukan penelitian darin sumber- sumber yang telah ada. Data ini biasanya diperoleh dari perpustakaan atau dari laporan-laporan penelitian (Hasan,2010). Data sekunder yang dipergunakan peneliti dalam penelitian ini terdiri dari buku-buku, jurnal-jurnal penelitian, dan laporan keuangan perusahaan yang masuk pada kelompok saham JII (Jakarta Islamic Index).

Menurut Kuncoro (2009), populasi merupakan kelompok elemen yang lengkap, dimana kita tertarik untuk mempelajarinya atau menjadi obyek penelitian

Populasi pada penelitian ini adalah kelompok saham Jakarta Islamic Index (JII) periode 1 Desember 2014 sampai dengan periode 31 Mei 2015 yang berjumlah 27 emiten atau perusahaan. sampel menurut Kuncoro (2009), merupakan himpunan bagian (subset) dari unit populasi.

Teknik sampel yang dipergunakan pada penelitian ini denga menggunakan purposive sampling Teknik sampel yang dipergunakan pada penelitian ini denga menggunakan purposive sampling diantaranya adalah pertama perusahaan saham termasuk pada kelompok saham saham Jakarta Islamic Index (JII) periode 1 Desember 2014 sampai dengan periode 31 Mei 2015, kedua Perusahaan saham termasuk pada kelompok saham saham Jakarta Islamic Index (JII) periode 1 Desember 2014 sampai dengan periode 31 Mei 2015 yang mengalami kerugian atau tidak untung, sehingga sampel penelitian menjadi 54 observasi pengamatan penelitian.

Teknik pengumpulan data pada penelitian ini dengan menggunakan teknik dokumentasi, yang menyebabkan peneliti menggunkan teknik dokumentasi 
dikarenakan secara umum peneliti menggunakan data sekunder.

Teknik pengumpulan data dengan metode dokumentasi adalah cara mencari data atau informasi dari buku-buku catatan-catatan, transkrip, surat kabar, majalah, prasasti, notulen rapat, legger, agenda, dan yang lainnya (Soewadji,2012). Teknik dokumentasi yang dipergunakan pada penelitian ini adalah dengan menggunakan laporan-laporan keuangan perusahaan yang masuk pada kelompok saham JII (Jakarta Islamic Index) dan datadata yang terkait pada penelitian ini.

Teknik analisis data pada penelitian dengan menggunakan 2 (dua) cara yaitu analisis regresi linier berganda (hipotesis pertama sampai dengan hipotesis keempat), dan uji interaksi (hipotesis kelima sampai dengan hipotesis kedelapan).

\section{HASIL DAN PEMBAHASAN}

Hasil pengujian pada penelitian ini dilakukan dengan dua teknik analisis yaitu dengan menggunakan analisis regresi linier berganda dan uji interaksi.

\section{a. Analisis Regresi Linier Berganda}

Sebelum dilakukannya analisis regresi linier berganda pada pengujian hipotesis pertama sampai dengan keempat, maka syarat yang harus dipenuhi yaitu uji asumsi klasik penelitian yang terdiri uji normalitas, uji heterokedastisitas, uji multikolinieritas dan uji autokorelasi, berikut ini penjelasan uji asumsi klasik penelitian:

\section{1) Uji Normalitas}

Uji normalitas untuk mengetahui apakah suatu data dalam penelitian berdistribusi normal atau tidak berdistribusi normal. Mengetahui data berdistribusi normal pada uji normalitas dapat menggunakan uji KolmogrovSmirnov, berikut ini hasil uji KolmogrovSmirnov pada pengujian normalitas:

\begin{tabular}{|c|c|c|}
\hline \multicolumn{3}{|c|}{ One-Sample Kolmogorov-Smirnov Test } \\
\hline & & $\begin{array}{l}\text { Unstandardiz } \\
\text { ed Residual }\end{array}$ \\
\hline $\mathrm{N}$ & & 54 \\
\hline Normal Parameters ${ }^{2}$ & Mean & .0000000 \\
\hline & Std. Deviation & $6.59345842 \mathrm{E} 3$ \\
\hline Most Extreme Differences & Absolute & .107 \\
\hline & Positive & .107 \\
\hline & Negative & -.059 \\
\hline Kolmogorov-Smirnov $Z$ & & .787 \\
\hline Asymp. Sig. (2-tailed) & & .565 \\
\hline
\end{tabular}

Berdasarkan pada one sample kolmogrov-smirnov test dapat diketahui bahwa nilai signifikansi pada asymp.Sig (2-tailed) sebesar 0.565 atau di atas 0.05, sehingga data terdistribusi normal.

\section{2) Uji Heterokedastisitas}

Uji heterokedastisitas dapat berfungsi seberapa peranan variabel bebas terhadap variabel terikat secara residual. Berikut ini hasil uji heterokedastisitas pada penelitian ini adalah:

\begin{tabular}{|c|c|c|c|c|c|c|}
\hline \multicolumn{7}{|c|}{ Coeficieients } \\
\hline \multirow[b]{2}{*}{ 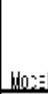 } & & \multicolumn{2}{|c|}{ Lnsta Legrdied Coeff cie`-1s } & 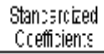 & \multirow[b]{2}{*}{1} & \multirow[b]{2}{*}{ Eilg. } \\
\hline & & B & S.d. Error & E:la & & \\
\hline \multirow[t]{5}{*}{1} & (i:- stani! & 8729.376 & $1(28.2 \pm=$ & & $\vdots 627$ & J \\
\hline & 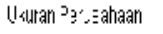 & $-5.73 \mathrm{E}-12$ & $0=$ & .043 & .308 &.$i \equiv c$ \\
\hline & Frofit:tilil:ss & $\because .7 \pm 3$ & $92.54:$ & $\cdot 0^{\prime} ?$ & $\therefore 2 \pi$ & 30 \\
\hline & volailizsPenda:zlan & $1(334.3=4$ & 535.97 & 260 & 1.867 &.$j \approx \varepsilon$ \\
\hline & P:scik: Eisnis & $.110^{\circ} .371$ & $1: 03.8:=$ & .16 & .845 & 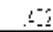 \\
\hline
\end{tabular}

Berdasarkan pada coeeficents dapat diketahui pada variabel bebas yang terdiri dari ukuran perusahaan, profitabilitas, volatilitas pendapatan, dan resiko bisnis memiliki nilai sig diatas 0.05 sehingga tidak terjadi gejala heterokedastisitas pada penelitian ini

\section{3) Uji Multikolinieritas}

Uji multikolinieritas berfungsi untuk mengetahui apakah ada terjadi hubungan setiap variabel bebas. Mendeteksi multikolinieritas dapat menggunakan nilai 
tolerance dan nilai VIF, berikut ini hasil uji multikolinieritas pada penelitian ini adalah:

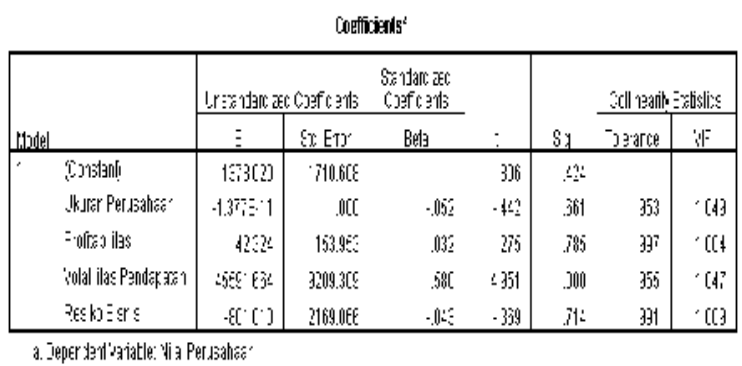

Berdasarkan pada coeeficients pada pengujian multikolinieritas yaitu dapat terlihat nilai tolerance dan nilai VIF pada variabel ukuran perusahaan memiliki nilai tolerance sebesar 0.953 dan VIF sebesar 1.049 , nilai tolerance dan nilai VIF pada variabel profitabilitas memiliki nilai tolerance sebesar 0.997 dan VIF sebesar 1.004, nilai tolerance dan nilai VIF pada variabel volatilitas pendapatan memiliki nilai tolerance sebesar 0.955 dan VIF sebesar 1.047, nilai tolerance dan nilai VIF pada variabel resiko bisnis memiliki nilai tolerance sebesar 0.991 dan VIF sebesar 1.009, dapat dikatakan tidak terjadi multikolinieritas apabila nilai tolerance > 0.1 dan nilai VIF $<10$, pada hasil penelitian nilai tolerance $>0.1$ dan VIF $<$ 10 sehingga tidak terjadi multikolinieritas pada penelitian ini.

\section{4) Uji Autokorelasi}

Uji autokorelasi sangat berfungsi untuk mengetahui apakah ada atau tidaknya kesalahan penganggu pada periode waktu sekarang dengan periode waktu sebelumnya. Mendeteksi ada atau tidaknya terjadi autokorelasi dapat dilakukan dengan menggunakan DurbinWatson (DW), berikut ini hasil pengujian autokorelasi dengan menggunakan DW adalah sebagai berikut:

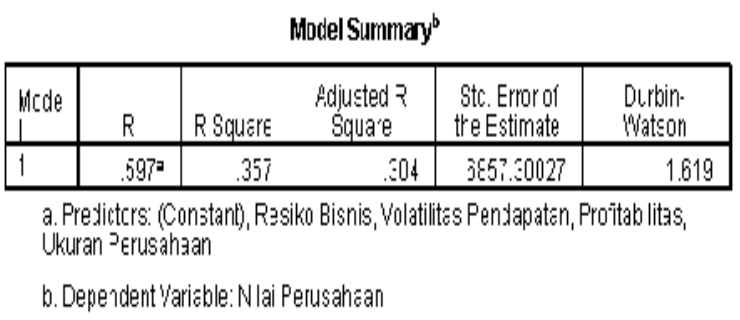

Berdasarkan pada model summary bahwa dapat diketahui nilai DurbinWatson (DW) sebesar 1.619 dengan $\mathrm{dl}=$ 1.4069 dan $\mathrm{du}=1.7234$, dengan hasil 4 $\mathrm{du}=4-1.7234=2.2766$ sehingga $1.7234>1.619<2.2766$ dapat disimpulkan terjadi autokorelasi. Peneliti mengobati autokorekasi dengan cara melakukan Ln (Logaritma Natural) pada semua variabel bebas dan variabel terikat, berikut ini DW setelah dilakukannya Ln (Logaritma Natural) adalah:

\begin{tabular}{|c|c|c|c|c|c|}
\hline \multicolumn{6}{|c|}{ Model Summary' } \\
\hline Mode & $\mathrm{R}$ & B.sq.are & $\begin{array}{l}\text { iddusted R } \\
\text { Square } \\
\end{array}$ & $\begin{array}{l}\text { Etdd Error of } \\
\text { the Estimate }\end{array}$ & $\begin{array}{l}\text { Curbin- } \\
\text { Wals]r }\end{array}$ \\
\hline 1 & $.451^{2}$ & .202 & 076 & .93223 & 1.775 \\
\hline \multicolumn{6}{|c|}{ 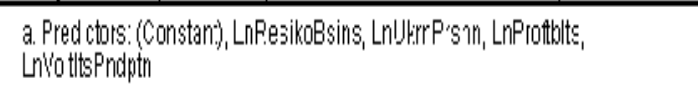 } \\
\hline \multicolumn{6}{|c|}{ b. Dependen: Variabla: LnN|ïiFrshn } \\
\hline
\end{tabular}

Berdasarkan model summary setelah dilakukannya Ln nilai DW sebesar 1.775 dengan $\mathrm{dl}=1.4069$ dan $\mathrm{du}=1.7234$, dengan hasil $4-\mathrm{du}=4-1.7234=2.2766$ sehingga $1.7234<1.775<2.2766$ dapat disimpulkan tidak terjadi autokorelasi.

Setelah dilakukannya uji asumsi klasik, maka langkah selanjutnya dilakukannya analisis regresi linier berganda yang terdiri dari koefisien determinasi (R2), uji simultan (uji-F) dan uji parsial, berikut ini penjelasannya:

\section{a. Koefisien Determinasi (R2)}

Koefisien determinasi dapat berguna untuk melihat kemampuan model dari variabel bebas terhadap variabel terikat. 


\section{Model Summary

\begin{tabular}{|c|c|c|c|c|}
\hline Mode & $R$ & R Squate & $\begin{array}{l}\text { kdustust R } \\
\text { Soquale }\end{array}$ & $\begin{array}{l}\text { Sod Error of } \\
\text { the Estinate }\end{array}$ \\
\hline 1 & 5972 & .357 & 304 & $6057,3000 ?$ \\
\hline
\end{tabular}

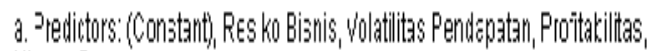 Ukuâ ${ }^{2}$ evusa}

Berdasarkan pada model summary bahwa nilai adjusted $\mathrm{R}$ square sebesar 0.304 atau $30.4 \%$ sehingga dapat dinyatakan ukuran perusahaan, profitabilitas, volatilitas pendapatan dan resiko bisnis dapat dijelaskan sebesar $30.4 \%$ sehingga sisanya diluar faktor yang tidak diteliti dalam penelitian ini.

\section{b. Uji secara simultan}

Uji secara simultan ini berfungsi untuk melihat kemampuan apakah ukuran perusahaan, profitabilitas, volatilitas pendapatan, resiko bisnis terhadap nilai perusahaan secara simultan pada saham JII (Jakarta Islamic Indeks) di Bursa Efek Indonesia. berikut ini hasil pengujian secara simultan pada penelitian ini adalah:

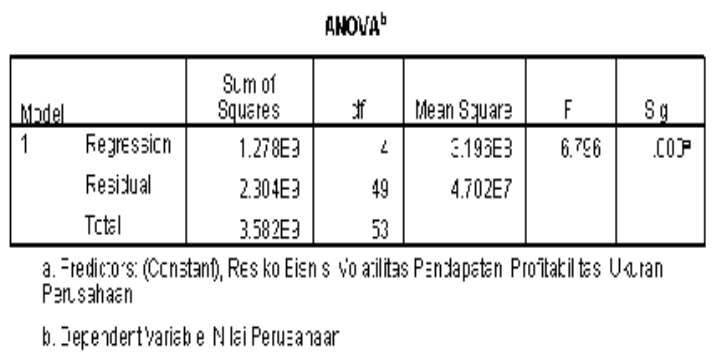

Berdasarkan pada Anova yang dilakukan pada secara simultan bahwa ukuran perusahaan, profitabilitas, volatilitas pendapatan, dan resiko bisnis berpengaruh simultan terhadap nilai perusahaan pada saham JII (Jakarta Islamic Indeks) di Bursa Efek Indonesia, yaitu dengan Fhitung sebesar 6.766 dan Ftabel sebesar 2.54 atau $6.766>2.54$.

\section{c. Uji secara parsial}

Uji secara parsial untuk melihat kemampuan apakah ukuran perusahaan, profitabilitas, volatilitas pendapatan, resiko bisnis terhadap nilai perusahaan secara parsial pada saham JII (Jakarta Islamic Indeks) di Bursa Efek Indonesia. Berikut ini hasil pengujian secara parsial adalah:

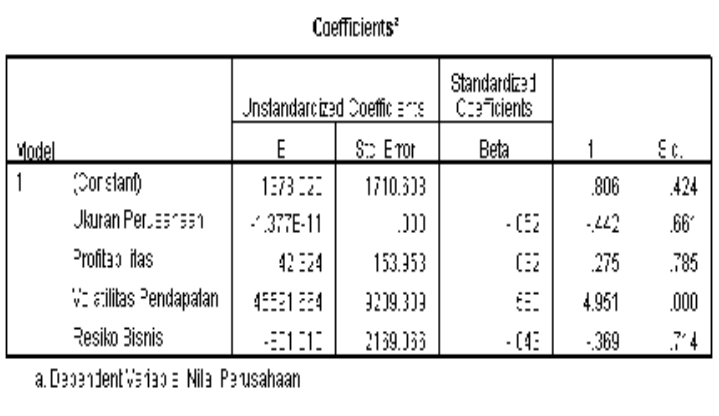

Berdasarkan pada coefficients dapat diketahui bahwa:

1. Pengaruh ukuran perusahaan terhadap nilai perusahan pada saham JII (Jakarta Islamic Indeks) di Bursa Efek Indonesia.

Ukuran perusahaan tidak berpengaruh terhadap nilai perusahaan pada sahaam JII (Jakarta Islamic Indeks) di Bursa Efek Indonesia dengan thitung sebesar -0.442 dan $t_{\text {tabel }}$ sebesar 1.67356 atau $-0.442<$ 1.67356 dengan sig 0.661 diatas 0.05 atau $5 \%$.

Hasil penelitian ini tidak sejalan oleh hasil penelitian yang dilakukan Pratama dan I Gusti Bagus Wiksuana (2016), bahwa ukuran perusahaan berpengaruh terhadap nilai perusahaan, sedangkan sejalan dengan hasil penelitian yang dilakukan oleh Hasania dkk (2016), bahwa ukuran perusahaan tidak berpengaruh terhadap nilai perusahaan.

\section{Pengaruh profitabilitas terhadap} nilai perusahan pada saham JII (Jakarta Islamic Indeks) di Bursa Efek Indonesia.

Profitabilitas tidak berpengaruh terhadap nilai perusahaan pada sahaam JII (Jakarta Islamic Indeks) di Bursa Efek Indonesia dengan thitung sebesar 0.275 dan $t_{\text {tabel }}$ 
sebesar 1.67356 atau $0.275<1.67356$ dengan sig 0.785 diatas 0.05 atau $5 \%$.

Hasil penelitian ini tidak sejalan oleh hasil penelitian yang dilakukan Pratama dan I Gusti Bagus Wiksuana (2016), bahwa profitabilitas berpengaruh terhadap nilai perusahaan, hal ini berarti bahwa profitabilitas atau keuntungan yang tinggi tidak dapat memicu naiknya nilai perusahaan pada saham JII, dikarenakan walaupun harga saham pada saham JII mengalami penurunan keuntungan, investor akan tetap melakukan pembelian saham JII tersebut.

\section{Pengaruh volatilitas pendapatan} terhadap nilai perusahan pada saham JII (Jakarta Islamic Indeks) di Bursa Efek Indonesia.

Volatilitas pendapatan berpengaruh terhadap nilai perusahaan pada sahaam JII (Jakarta Islamic Indeks) di Bursa Efek Indonesia dengan thitung sebesar 4.951 dan tabel sebesar 1.67356 atau $4.951>1.67356$ dengan sig 0.05 dibawah 0.05 atau 5\%. Hal ini disebabkan bahwa saham JII memiliki tingkat resiko yang kecil sehingga keuntungan pendapatannya selalu stabil oleh sebab itu investor selalu menginvestasikan uangnya atau dananya pada saham JII.

\section{Pengaruh resiko bisnis terhadap nilai} perusahan pada saham JII (Jakarta Islamic Indeks) di Bursa Efek Indonesia.

Resiko bisnis tidak berpengaruh terhadap nilai perusahaan pada saham JII (Jakarta Islamic Indeks) di Bursa Efek Indonesia dengan $t_{\text {hitung }}$ sebesar -0.369 dan $t_{\text {tabel }}$ sebesar 1.67356 atau $-0.369<1.67356$ dengan sig 0.714 diatas 0.05 atau 5\%. Hal ini menunjukkan bahwa apabila resiko bisnis meningkatkan maka perusahaan tidak akan berdampak pada nilai perusahaan, hal ini disebabkan bahwa resiko bisnis yang dialami pada saham JII sangat kecil karena harga saham pada JII selalu stabil sehingga tidak berdampak langsung terhadap nilai perusahaan.

\section{b. Uji Interaksi}

uji interaksi ini dilakukan uji menguji variabel moderating pada penelitian ini. Berikut ini hasil pengujian interaksi pada variabel moderating adalah:

1. Pengaruh Ukuran Perusahaan, dan Kebijakan Hutang Terhadap Nilai Perusahaan pada saham JII (Jakarta Islamic Indeks) di Bursa Efek Indonesia.

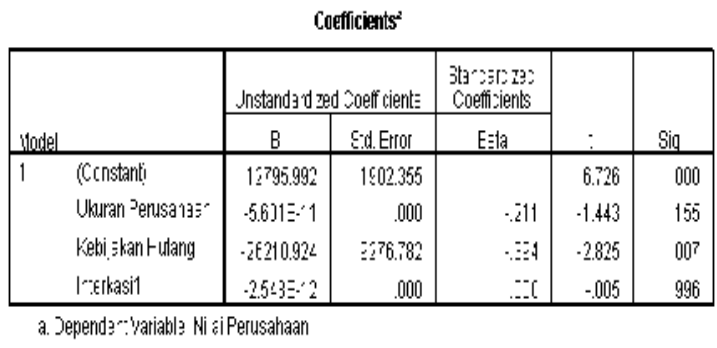

Hasil penelitian ini menunjukkan bahwa kebijakan hutang tidak memberikan hubungan antara ukuran perusahaan dan nilai perusahaan. Hal ini disebabkan bahwa kebijakan hutang yang besar maupun hutang yang kecil tidak akan mempengaruhi nilai suatu perusahaan.

\section{Pengaruh Profitabilitas, dan} Kebijakan Hutang Terhadap Nilai Perusahaan pada saham JII (Jakarta Islamic Indeks) di Bursa Efek Indonesia. 


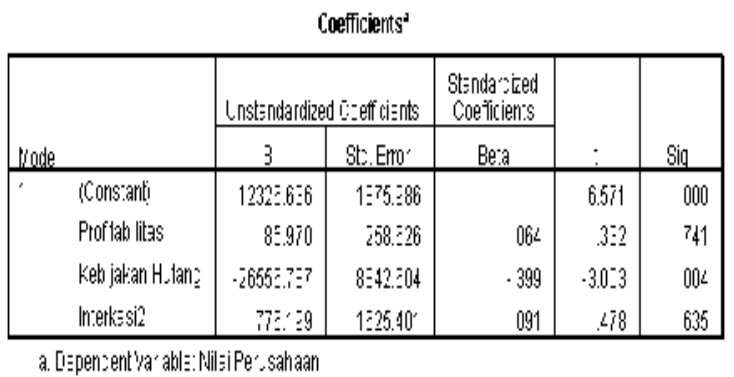

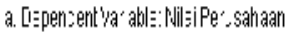

Hasil penelitian ini menunjukkan bahwa kebijakan hutang tidak memberikan hubungan antara profitabilitas dan nilai perusahaan. Hal ini disebabkan bahwa meskipun hutang mengalami peningkatan maupun penurunan tidak dapat menyebabkan nilai perusahaan mengalami perubahan sedikitpun.

\section{Pengaruh Volatilitas Pendapatan,} dan Kebijakan Hutang Terhadap Nilai Perusahaan pada saham JII (Jakarta Islamic Indeks) di Bursa Efek Indonesia.

\begin{tabular}{|c|c|c|c|c|c|c|}
\hline \multirow[b]{2}{*}{ Mradel } & & \multicolumn{2}{|c|}{ 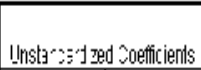 } & \multirow{2}{*}{$\begin{array}{l}\text { Ecrcercicj } \\
\text { Doeff jents } \\
\text { Eela }\end{array}$} & \multirow[b]{2}{*}{$t$} & \multirow[b]{2}{*}{ 3: } \\
\hline & & $B$ & $S: \mathrm{Er}^{\prime} \mathrm{O}^{\prime}$ & & & \\
\hline & (G)onst:- & 273.1216 & $25) 4 \leqslant[\varepsilon$ & & 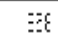 & .390 \\
\hline & volab las Pendapatan & 58745.938 & $125 j: \leqslant 41$ & $74:$ & הביבו & .000 \\
\hline & ketijaka I Iutang & $\cdots 7.473$ & $1 \leq 33: 12 E$ & $1 \geqq$ & 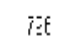 & .430 \\
\hline & Interak: : & $.2305^{\circ} 9.931$ & 11333101 & .4 .2 & 1 & .053 \\
\hline
\end{tabular}

Hasil penelitian ini menunjukkan bahwa kebijakan hutang memberikan hubungan antara volatilitas pendapatan dan nilai perusahaan. Temuan hasil penelitian ini mengarahkan bahwa naiknya resiko bisnis tidak dapat memberikan kontribusi terhadap nilai perusahaan

\section{Pengaruh Resiko Bisnis, dan Kebijakan Hutang Terhadap Nilai Perusahaan pada saham JII (Jakarta Islamic Indeks) di Bursa Efek Indonesia.}

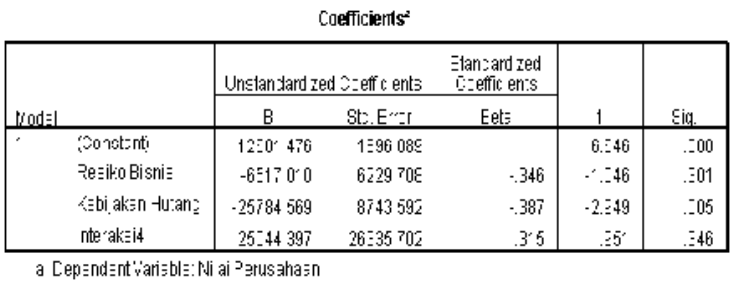

Hasil penelitian ini menunjukkan bahwa kebijakan hutang tidak memberikan hubungan antara resiko bisnis dan nilai perusahaan. Temuan hasil penelitian ini mengarahkan bahwa naiknya resiko bisnis tidak dapat memberikan kontribusi terhadap nilai perusahaan.

\section{KESIMPULAN DAN SARAN}

\section{a. Kesimpulan}

Kesimpulan yang dapat disimpulkan pada penelitian ini adalah:

1. Secara simultan ukuran perusahaan, profitabilitas, volatilitas pendapatan, dan resiko bisnis berpengaruh simultan terhadap nilai perusahaan pada saham JII (Jakarta Islamic Indeks) di Bursa Efek Indonesia

2. Secara parsial volatilitas pendapatan berpengaruh terhadap terhadap nilai perusahaan pada sahaam JII (Jakarta Islamic Indeks) di Bursa Efek Indonesia.

3. Menunjukkan bahwa kebijakan hutang tidak memberikan hubungan antara ukuran perusahaan, profitabilitas, resiko binis dengan nilai perusahaan, sedangkan volatilitas pendapatan memberikan hubungan terhadap nilai perusahaan dengan kebijakan hutang sebagai moderating.

\section{b. Saran}

Saran yang dapat diharapkan pada penelitian ini adalah pertama dapat menambah variabel terikat yang lain nyaselain nilai perusahaan yang 
mempengaruhi ukuran perusahaan, profitabilitas, volatilitas pendapatan dan resiko bisnis, kedua waktu penelitian tidak hanya pada waktu dua tahun tetapi lima tahun, ketiga menambahkan variabel moderating laiinya seperti pertumbuhan perusahaan atau yang lainnya.

\section{DAFTAR PUSTAKA}

Hasania Zurhria, Sri Murni, dan Yunita Mandige,2016. Pengaruh Current Ratio, Ukuran Perusahaan, Struktur Modal, dan ROE Terhadap Nilai Perusahaan Farmasai yang Terdaftar Di Bursa Efek Indonesia Periode 2011 - 2014. Jurnal Berkala Ilmiah Efisiensi, Volume 16, No. 03.

Hasan Iqbal,2010. Analisis Data Penelitian Dengan Statistik. Penerbit PT. Bumi Aksara. Jakarta.

Imanta Dea dan Rutji Satwiko, 2011. Faktor-Faktor yang Mempengaruhi Kepemilikan Manajerial. Jurnal Bisnis dan Akuntansi, Volume 13, Nomor 01. Kuncoro Mudrajad,2009. Metode Riset Untuk Bisnis dan Ekonomi. Penerbit Erlangga.

Novari Putu Mikhy dan Putu Vivi Lestari,2016. Pengaruh Ukuran Perusahaan, Leverage, dan Profitabilitas Terhadap Nilai Perusahaan Pada Sektor Properti dan Real Estate. E- Jurnal Manajemen Unud, Volume 5, No. 09.

Pratama I Gusti Bagus Angga dan I Gusti Bagus Wiksuana,2016. Pengaruh Ukuran Perusahaan dan Leverage Terhadap Nilai Perusahaan Dengan Profitabilitas Sebagai Variabel Mediasi. E- Jurnal Manajemen Unud, Volume 5, No. 02.

Pratiwi Ni Putu Yuni, Fridayana Fudiaatmaja, dan I Wayan Suwendra,2016. Pengaruh Struktur
Modal dan Ukuran Perusahaan Terhadap Nilai Perusahaan. EJournal Bisma Universitas Pendidikan Ganesha, Volume 4.

Rudangga I Gusti Ngurah Gede dan Gede Merta Sudiarta, 2016. Pengaruh Ukuran Perusahaan, Leverage, dan Profitabilitas Terhadap Nilai Perusahaan. - Jurnal Manajemen Unud, Volume 5, No. 07.

Soewajdi Jusuf,2012. Pengantar Metodologi Penelitian. Penerbit Mitra Wacana Media. 